Research Article

\title{
The Effect of Competence, Organizational Commitment, and Perceived Organizational Support towards Service Quality and Working Group Performance of Procurement Service Unit in Ministry of Finance of Indonesia
}

\author{
Agus Heri Purnomo, Raden Andi Sularso, Ahmad Roziq* \\ Faculty of Economics and Business, University of Jember
}

\begin{abstract}
This research aims to examine and analyse the effects of competence, organizational commitment, and perceived organizational support towards the service quality and the working group performance of Procurement Service Unit in Ministry of Finance. It uses the quantitative method with explanatory research approach and Partial Least Square (PLS) as the method of data analysis. The sample of this research uses the census technique on entire population of working group (Pokja) of Procurement Service Unit (ULP) spread in Ministry of Finance, Jakarta. The primary data used in this research is the opinions of the head of working group about the variables. The results show that the competence significantly influences the service quality, and the service quality also materially affects the ULP working group performance. On the other hand, the result of this research reveals that the organizational commitment and perceived organizational support do not significantly influence the service quality and ULP working group performance.
\end{abstract}

Keywords: competence, organizational commitment, perceived organizational support, service quality and ULP working group performance.

\section{Introduction}

Bureaucratic reform in all sectors is necessary to carry out as an effort to achieve good governance dan clean governance in the implementation of government duties, including the procurement reform of government goods and services. The Government Goods and Service Procurement Policy Agency (LKPP) has formulated four pillars of reformation of government procurement / procurement: (1) the pillar of regulation, (2) the pillar of institution and human resources, (3) the pillar of market practice and (4) the pillar of integrity (Prabowo, 2015).

In line with this program, the Ministry of Finance launches the procurement transformation programme as an effort to strengthen the procurement and management of assets within the Ministry of Finance. To achieve the effort, the Ministry of Finance establishes the cooperation with LKPP in the form of Procurement Modernization Programme which includes the affirmation of procurement agency, the realization of professional procurement human resources, the creation of role and institutional procurement function, and the realization of efficient and effective procurement through the systematic procurement performance (Warta Eproc, Edition XVI:31).

The phenomenon that occurs in the Procurement Service ULP (ULP) in Ministry of Finance is the existence of some problems faced by the Working Group (Pokja) of ULP in Ministry of Finance. Sumarsono (2017) conveys several problems faced by ULP with the form of the impermanent organization as well as ULP in Ministry of Finance, such as (1) the existence of scattered procurement organizations causes the difficulty in preparing the consolidated procurement plan and the difficulty in supervising and providing the legal protection for the working group personnel of ULP, (2) the working groups of ULP that work part-time causes the lack of professionalization in procurement, and the focus of procurement is solely on the process of selecting goods or services providers. Through the Procurement Modernization programme, like the realization of professional procurement human resources is expected to improve the competence of the Working Group (Pokja) of ULP.

Ivancevich et al. (2007: 83) explains that the factors of personality, ability and skill, perception and attitude influence the work behaviors, such as productivity, creativity, and performance. The competence is an ability to perform a task or job based on knowledge, skills, and supported by attitudes that become individual characteristics (Wibowo, 2011: 324). Surjadi (2012: 9) states that the aspect of human resources is one element of the development of public service quality in which the competence of service providers is considered as one element of service standards that must be owned by service personnel. Nurmashita et al. (2013) and Gunadi et al. (2015) finds that the competence has a significant effect on service quality.

In addition, the competence has an important role to improve the organizational performance because it involves the basic ability of person in doing the job (Sriwidodo and Haryanto, 2010). With inadequate competence, a person will be difficult to complete the job on time and with the standards that have been required. In collective situations, the competence is a key of organizational success (Sedarmayanti, 2013: 127). Meanwhile, Ratnasari's research (2016) indicates that the competence insignificantly affects the performance of 


\section{Ahmad Roziq et al / The Effect of Competence, Organizational Commitment, and Perceived Organizational Support towards Service Quality and Working Group Performance of Procurement Service Unit in Ministry of Finance of Indonesia}

employees

Organizational commitment is a part of person's attitudes towards his or her organization. It plays an important role in improving the service quality and achieving the organizational success. Robbins and Judge (2006: 72-74) define the organizational commitment as a situation where an individual is on the side of the organization and his goals and his desire are used to maintain his membership within the organization. Unzicker et al. (in Hidayat, 2010) declares that the service quality received by customers is due to the commitment of employees toward the organization. In the research, Hidayat (2010) and Sujarwo (2016) find that organizational commitment has a significant effect on service quality.

Siagian (2002) claims there are many factors that influence the performance of public sector organization, such as organizational commitment. Kurniawan's (2013) and Hafidhah, et al. (2014) explain that the organizational commitment also had a significant effect on organizational performance. On the other hand, Abdullah and Arisanti (2010) show that it had no significant effect on organizational performance.

The perception of organizational support is 'how far' the employees believe that the organization values their contribution and cares about their well-being (Robbins \& Judge, 2013: 76). Surjadi (2012: 9) argues there are two aspects in improving the quality of public services; the aspect of service processes and human resources service providers, and the institutional aspect of service providers. One example of the institutional aspects of service providers is the existence of the optimal organizational support for the employees as the service providers. The employees who have high perceptions of support from their organization will produce the excellent service quality for the community. The research of DonHee, et al. (2011) and Garg, et al. (2014) show that the perception of organizational support has a significant effect on service quality.

Mathis and Jackson (in Kaswan, 2015: 248) argue that the achievement of organizational goals for employee's performance is influenced by three factors: (1) the ability of individuals, (2) the effort, and (3) the organizational support. The high level perceived organizational support by employees can influence the success of organization performance. The research of Indarjanti et al. (2012) and Susmiati, et. al (2015) show that the perception of organizational support has a significant effect on organizational performance. Conversely, Kambu, et al. (2011) determines that the perceptions of organizational support had no significant effect on employee performance.

The service quality can be interpreted as an effort to meet the needs and desires of consumers, and the accuracy of delivery to balance the consumer expectations (Tjiptono, 2008: 59). Kawahe, et al. (2016) argues that there are many factors that influence the performance of the organization, such as how the organization performs the service function to the public. The research of Churiyah (2007) and Kawahe, et al. (2016) claim that the service quality has a significant effect on organizational performance. Based on the phenomena and differences of previous research findings, the purpose of this research is to examine and analyze the variables affecting the service quality and the performance of ULP Working Group in Ministry of Finance.

\section{Research Hypothesis}

To give clear directions, the hypothesis is formulated as follows:

H1 : the competence affects the service quality

$\mathrm{H} 2$ : the organizational commitment affects the service quality

H3 : the organizational support affects the service quality

H4 : the competence affects the performance of ULP Working Group

H5 : the organizational commitment affects the performance of ULP Working Group

H6 : the organizational support affects the performance of ULP Working Group

H7 : the service quality significantly affects the performance of ULP Working Group

\section{Conceptual Framework}

Furthermore, the hypothesis has been formulated in the conceptual framework of research as shown in Figure 1:

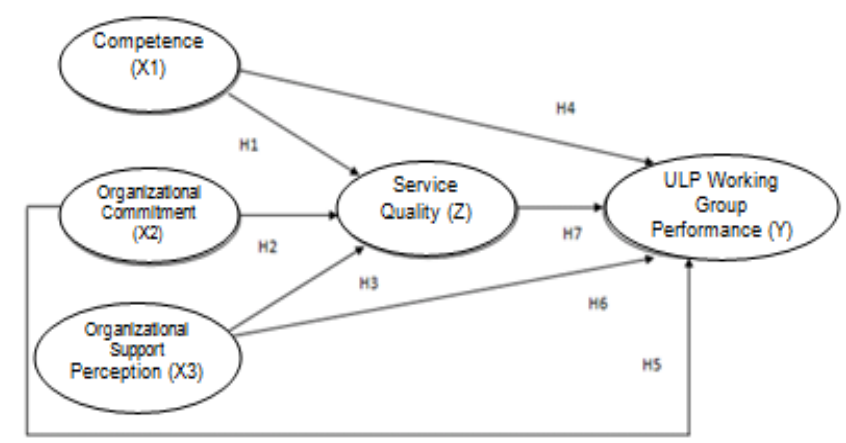

Figure 1. Conceptual Framework

\section{Research Methodology}

This research uses the quantitative method with explanatory research approach. The method of data analysis is Partial Least Square (PLS) with software SmartPLS. The sample of this research is taken by using census technique on entire population of working group (Pokja) of Procurement Service Unit (ULP) spread in 11 units of Eselon I in Ministry of Finance in Jakarta. The primary data used in this research involves 38 respondents.

The variables used in this research consist of independent variables, such as competence (X1), organizational commitment (X2), and organizational support (X3); intervening or intermediary variables in the form of service quality (Z1) and dependent variable in the form of ULP Working Group performance (Y1). The operational definition of variables and its indicator can be seen in Table 1 below: 
Ahmad Roziq et al / The Effect of Competence, Organizational Commitment, and Perceived Organizational Support towards Service Quality and Working Group Performance of Procurement Service Unit in Ministry of Finance of Indonesia

Table 1. The Operational Definition and Indicator of Variable

\begin{tabular}{lll}
\hline Variabel & finisi Operasional & Indikator \\
\hline Competence $\left(\mathrm{X}_{1}\right)$ & The abilities and the characteristics of ULP working & a. Knowledge $\left(\mathrm{X}_{1.1}\right)$ \\
& group, in the form of knowledge, skills, and attitudes, & b. Skill $\left(\mathrm{X}_{1.2}\right)$ \\
& acquired to carry out the task of selecting the provider & c. Attitude $\left(\mathrm{X}_{1.3}\right)$ \\
& of goods and services professionally, effectively, and \\
& efficiently.
\end{tabular}

\section{Organizational} commitment $\left(\mathrm{X}_{2}\right)$ A condition in

A condition in which member of ULP working group
sides with the interests, mission, and vision of the organization to retain the membership as the member a. Affective commitment $\left(\mathrm{X}_{2.1}\right)$

b. Continuance commitment $\left(\mathrm{X}_{2.2}\right)$

c. Normative commitment $\left(\mathrm{X}_{2.3}\right)$ of ULP working group

\begin{tabular}{lll}
\hline Organizational & Support & A condition in which the member believes that the \\
& supervisor of organization values their contribution and & b. Perception of cares $\left(X_{3.2}\right)$ \\
& cares about their well-being & c. Perception of well-being $\left(X_{3.3}\right)$
\end{tabular}
An effort to fulfil the needs and expectations of service a. Tangibles $\left(Z_{1.1}\right)$ users of ULP working group as well as the accuracy of $b$. Reliability $\left(Z_{1.2}\right)$ its delivery in meeting the expectation of service user c. Responsiveness $\left(Z_{1.3}\right)$ of ULP working group
d. Assurance $\left(Z_{1.4}\right)$
e. Empathy $\left(Z_{1.5}\right)$

\section{Result}

The outer model describes the relationship between each indicator block and its latent variables. The reflective indicator of outer model is carried out by the following three tests:

\section{Convergent Validity Test}

The convergent validity used in this research is the value of loading factor $>0,60$. In the first stage of convergent validity test, there are tangible indicator $\left(\mathrm{Z}_{\cdot_{1.1}}\right)$ and effective indicator

Table 2. Factorloading value (Stage I, II, and III)
$\left(\mathrm{Y}_{\cdot 1.1}\right)$ that have factor loading value 0,469 and 0,460 so that both indicators are excluded from the measurement model. In the second test, the attitude indicator $\left(\mathrm{X}_{\cdot 1.3}\right)$ has factor loading value 0,598 so that it is also excluded from the measurement model. In the third stage of test, all indicators have factor loading values above 0,6 which mean the measurement model has completed the convergent validity. The factorloading value of each indicator in the third stage of convergent validity test can be seen in Table 2. Meanwhile, the structural equation path diagram can be seen in Figure 2.

\begin{tabular}{clll}
\hline \multirow{2}{*}{ Indicator } & \multicolumn{2}{l}{ Factor Loading Value } & \\
\cline { 2 - 4 } & Stage I & Stage II & Stage III \\
\hline$X_{1}$ & 0,867 & 0,873 & 0,919 \\
$X_{1.1}$ & 0,745 & 0,741 & 0,780 \\
$X_{1.2}$ & & & \\
$X_{1.3}$ & 0,604 & $\mathbf{0 , 5 9 8}$ & -- \\
\hline$X_{2}$ & & & \\
$X_{2.1}$ & 0,869 & 0,868 & 0,868 \\
$X_{2.2}$ & 0,802 & 0,801 & 0,802 \\
$X_{2.3}$ & 0,649 & 0,653 & 0,655 \\
\hline$X_{3}$ & & & 0,874 \\
$X_{3.1}$ & 0,869 & 0,874 &
\end{tabular}


Ahmad Roziq et al / The Effect of Competence, Organizational Commitment, and Perceived Organizational Support towards Service Quality and Working Group Performance of Procurement Service Unit in Ministry of Finance of Indonesia

\begin{tabular}{cccc}
$\mathrm{X}_{3.2}$ & 0,962 & 0,961 & 0,961 \\
$\mathrm{X}_{3.3}$ & 0,923 & 0,919 & 0,920 \\
\hline $\mathrm{Z}_{1}$ & $\mathbf{0 , 4 6 9}$ & --- & 0,862 \\
$\mathrm{Z}_{1.1}$ & 0,845 & 0,859 & 0,825 \\
$\mathrm{Z}_{1.2}$ & 0,837 & 0,824 & 0,840 \\
$\mathrm{Z}_{1.3}$ & 0,855 & 0,845 & 0,878 \\
$\mathrm{Z}_{1.4}$ & 0,866 & 0,879 & --- \\
$\mathrm{Z}_{1.5}$ & & & 0,649 \\
$\mathrm{Y}_{1}$ & $\mathbf{0 , 3 4 0}$ & 0,908 \\
$\mathrm{Y}_{1.1}$ & 0,669 & --- & 0,823 \\
$\mathrm{Y}_{1.2}$ & 0,898 & 0,659 & 0,846 \\
$\mathrm{Y}_{1.3}$ & 0,815 & 0,908 & 0,853 \\
$\mathrm{Y}_{1.4}$ & 0,835 & 0,822 & 0,659 \\
$\mathrm{Y}_{1.5}$ & 0,855 & 0,842 & 0,850 \\
$\mathrm{Y}_{1.6}$ & 0,654 & 0,657 & \\
$\mathrm{Y}_{1.7}$ & & & \\
\hline
\end{tabular}

Source : Bootstrapping Results

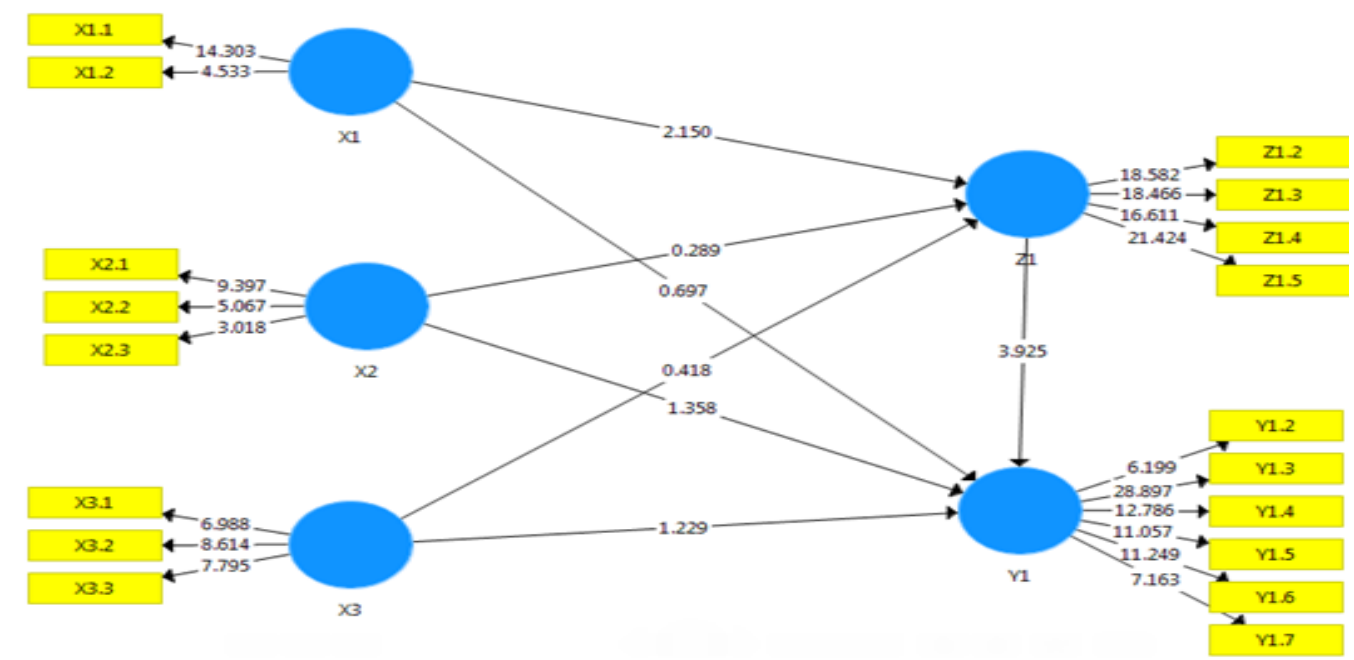

Figure 2. Structural Equation Path Diagram

Source: output PLS

\section{Discriminant Validity Test}

The discriminant validity is assessed by using the indicator of cross-loading factor with its latent construct. The result of discriminant validity test can be shown in Table 3:

Table 3. The Result of Discriminant Validity (Cross Loadings Factor)

\begin{tabular}{llllll}
\hline Indikator & $\mathrm{X}_{1}$ & $\mathrm{X}_{2}$ & $\mathrm{X}_{3}$ & $\mathrm{Z}_{1}$ & $\mathrm{Y}_{1}$ \\
\hline $\mathrm{X}_{1.1}$ & $\mathbf{0 , 9 1 9}$ & 0,485 & 0,324 & 0,487 & 0,518 \\
$\mathrm{X}_{1.2}$ & $\mathbf{0 , 7 8 0}$ & 0,348 & 0,206 & 0,329 & 0,305 \\
\hline $\mathrm{X}_{2.1}$ & 0,427 & $\mathbf{0 , 8 6 8}$ & 0,412 & 0,316 & 0,423 \\
$\mathrm{X}_{2.2}$ & 0,385 & $\mathbf{0 , 8 0 2}$ & 0,549 & 0,318 & 0,334 \\
$\mathrm{X}_{2.3}$ & 0,392 & $\mathbf{0 , 6 6 5}$ & 0,747 & 0,156 & 0,071 \\
\hline $\mathrm{X}_{3.1}$ & 0,338 & 0,585 & $\mathbf{0 , 8 7 4}$ & 0,267 & 0,150 \\
$\mathrm{X}_{3.2}$ & 0,314 & 0,654 & $\mathbf{0 , 9 6 1}$ & 0,280 & 0,173 \\
$\mathrm{X}_{3.3}$ & 0,240 & 0,505 & $\mathbf{0 , 9 2 0}$ & 0,296 & 0,166 \\
\hline $\mathrm{Z}_{1.2}$ & 0,453 & 0,451 & 0,342 & $\mathbf{0 , 8 6 2}$ & 0,740 \\
$\mathrm{Z}_{1.3}$ & 0,370 & 0,108 & 0,175 & $\mathbf{0 , 8 2 5}$ & 0,499 \\
$\mathrm{Z}_{1.4}$ & 0,225 & 0,286 & 0,331 & $\mathbf{0 , 8 4 0}$ & 0,444 \\
$\mathrm{Z}_{1.5}$ & 0,554 & 0,325 & 0,191 & $\mathbf{0 , 8 7 8}$ & 0,601 \\
\hline $\mathrm{Y}_{1.2}$ & 0,147 & 0,215 & $-0,005$ & 0,601 & $\mathbf{0 , 6 4 9}$ \\
$\mathrm{Y}_{1.3}$ & 0,507 & 0,344 & 0,244 & 0,749 & $\mathbf{0 , 9 0 8}$
\end{tabular}


Ahmad Roziq et al / The Effect of Competence, Organizational Commitment, and Perceived Organizational Support towards Service Quality and Working Group Performance of Procurement Service Unit in Ministry of Finance of Indonesia

\begin{tabular}{llllll}
$\mathrm{Y}_{1.4}$ & 0,399 & 0,367 & 0,173 & 0,519 & $\mathbf{0 , 8 2 3}$ \\
$\mathrm{Y}_{1.5}$ & 0,545 & 0,303 & 0,182 & 0,516 & $\mathbf{0 , 8 4 6}$ \\
$\mathrm{Y}_{1.6}$ & 0,426 & 0,402 & 0,144 & 0,375 & $\mathbf{0 , 8 5 3}$ \\
$\mathrm{Y}_{1.7}$ & 0,353 & 0,371 & 0,079 & 0,456 & $\mathbf{0 , 6 5 9}$ \\
\hline
\end{tabular}

Source: SmartPLS report

Table 3 shows that the value of crossloading factor for each indicator of each variable get the highest value than the value of loading factor for each indicator of other variables. It signifies that all variables have completed the discriminant validity.

\section{Composite Reliability Test}

Reliability test of this research is seen from the Composite Reliability (CR) value of each construct. The construct has a high level reliability if the CR value > 0,70 and AVE value > 0,50 . The result of composite reliability value is shown in Table 4 below:

Table 4. The Value of Composite Reliability and Average Variance Extracted

\begin{tabular}{llll}
\hline Variable & $C R$ & $A V E$ & Explanation \\
\hline Competence $\left(\mathrm{X}_{1}\right)$ & 0,840 & 0,726 & Reliable \\
\hline $\begin{array}{l}\text { Organizational } \\
\text { Commitment }\left(\mathrm{X}_{2}\right)\end{array}$ & 0,821 & 0,608 & Reliable \\
\hline $\begin{array}{l}\text { Organizational Support } \\
\text { Perception }\left(\mathrm{X}_{3}\right)\end{array}$ & 0,942 & 0,845 & Reliable \\
\hline Service Quality $\left(\mathrm{Z}_{1}\right)$ & 0,913 & 0,725 & Reliable \\
\hline $\begin{array}{l}\text { ULP Working Group } \\
\text { Performance }\left(\mathrm{Y}_{1}\right)\end{array}$ & 0,911 & 0,634 & Reliable \\
\hline
\end{tabular}

Source: Appendix 4.6 SmartPLS Report

Based on Table 4, it can be concluded that all constructs of the research fulfil the criteria of reliability shown by over 0,7 of Composite Reliability (CR) value and over 0,5 of Average Variance Extracted (AVE) value.

\section{Structural Model Test (Inner Model)}

Structural model test is carried out to know the relationship between the robust variable and the accurate one. It is measured by knowing the value of coefficient of determination (R-square) in each endogenous construct. The value of coefficient of determination is used to measure how much the level of variation of exogenous construct (competence, organizational commitment, and organizational support perception) which influences the endogenous constructs (service quality and ULP working group performance) The estimated result of R-square in endogenous construct can be seen in Table 5 .

Table 5 The Value of coefficient of determination ( $R$ square)

\begin{tabular}{ll}
\hline Dependent Variable & $R^{2}$ \\
\hline Service Quality $\left(\mathrm{Z}_{1}\right)$ & 0,270 \\
\hline ULP Working Group Performance & 0,558 \\
$\left(\mathrm{Y}_{1}\right)$ & \\
\hline
\end{tabular}

Source: Bootsrapping Result

Based on Table 5, the value of R-square for service quality variable (Z1) is 0,270 and for variable of ULP Working Group (Y1) is 0,558. It indicates that the independent variables of competence (X1), organizational commitment (X2), and organizational support perception (X3) affect the dependent variable of service quality (Z1) about $27.0 \%$ and $73.0 \%$ for the rest influenced by other factors outside the structural model. In addition, the independent variables of competence (X1), organizational commitment (X2), and organizational support perception (X3) also affect the dependent variable of ULP working group performance (Y1) about $55.8 \%$ and $44.2 \%$ for the rest influenced by other factors outside the structural model.

\section{Hypothesis Test}

The hypothesis formulated in this research will be accepted if it produces $t_{\text {count }}>2,024$ and $p_{\text {value }}<0,05$. Conversely, it will be rejected if it produces $t_{\text {count }}<2,024$ and $p_{\text {value }}>0,05$. The following table shows the estimated result to test structural model taken by ouput path coefficients in resampling bootstrap method.

Table 6 Output Value of Path Coefficients

\begin{tabular}{lllllll}
\hline Indicator & $\begin{array}{l}\text { Original } \\
\text { Sample }\end{array}$ & $\begin{array}{l}\text { Sample } \\
\text { Mean }\end{array}$ & $\begin{array}{l}\text { Standard } \\
\text { Deviation }\end{array}$ & T-Statistics & P-value & Conclusion \\
\hline $\mathrm{H}_{1}: \mathrm{X}_{1} \rightarrow \mathrm{Z}_{1}$ & 0,413 & 0,426 & 0,191 & 2,163 & 0,031 & Significant \\
\hline $\mathrm{H}_{2}: \mathrm{X}_{2} \rightarrow \mathrm{Z}_{1}$ & 0,080 & 0,083 & 0,282 & 0,285 & 0,776 & Insignificant \\
\hline $\mathrm{H}_{3}: \mathrm{X}_{3} \rightarrow \mathrm{Z}_{1}$ & 0,122 & 0,135 & 0,289 & 0,424 & 0,672 & Insignificant \\
\hline $\mathrm{H}_{4}: \mathrm{X}_{1} \rightarrow \mathrm{Y}_{1}$ & 0,151 & 0,142 & 0,208 & 0,728 & 0,467 & Insignificant \\
\hline $\mathrm{H}_{5}: \mathrm{X}_{2} \rightarrow \mathrm{Y}_{1}$ & 0,266 & 0,247 & 0,196 & 1,354 & 0,176 & Insignificant \\
\hline $\mathrm{H}_{6}: \mathrm{X}_{3} \rightarrow \mathrm{Y}_{1}$ & $-0,291$ & $-0,166$ & 0,193 & 1,138 & 0,256 & Insignificant \\
\hline $\mathrm{H}_{7}: \mathrm{Z}_{1} \rightarrow \mathrm{Y}_{1}$ & 0,590 & 0,600 & 0,145 & 4,063 & 0,000 & Significant \\
\hline $\mathrm{SOu}$ & & & &
\end{tabular}

Source: Bootstrapping result 


\section{Ahmad Roziq et al / The Effect of Competence, Organizational Commitment, and Perceived Organizational Support towards Service Quality and Working Group Performance of Procurement Service Unit in Ministry of Finance of Indonesia}

\section{Discussion}

The Influence of Competence on Service Quality

The result of coefficient test in Table 6 shows that the competence has significant effect on service quality. It means that the higher the competency of ULP working group is, the better the service quality of ULP working group has. The high level knowledge and skills of ULP working group will impact on the service quality provided by ULP working group to service users.

Surjadi (2012:9) states that the public service quality is always related to three main elements, one of them is the element of service provider resources in which the public service quality will be achieved if service provider resources have competencies in accordance with service standards. Therefore, the competence is required by the employees in giving the services based on the service standards.

The findings of this research support the research of Nurmasitha et al. (2013) and Gunadi et al. (2015) which conclude that the competence has a significant effect on the service quality. Based on the analysis of research results, it can be deduced that the competence variables significantly affect the service quality of Procurement Services Unit in Ministry of Finance.

The Influence of Organizational Commitment on Service Quality. The result of coefficient test in Table 6 shows that organizational commitment does not significantly affect the service quality. It signifies that the high level organizational commitment consisting of affective commitment, continuous commitment, and normative commitment is still not able to improve the service quality. Based on the results of the research, the indicator of normative commitment has the lowest correlation value with its construct when it is compared with the correlation value of the indicator of affective commitment and continuous commitment. This is indicated by the large number of ULP working group members that still have desire to quit as members of ULP working group.

Unzicker et al. in Hidayat (2010) describes that the service quality received by customers is the commitment owned by employees to the organization. The service quality provided by employees can be differentiated based on the level of the organizational commitment. Thus, the low level of organizational commitment of the employees forces them to provide minimum services.

The results of this research do not support Sujarwo (2016) that concludes the organizational commitment has a significant influence on service quality. In one hand, it also does not espouse Hidayat's research (2010) that defines the organizational commitment with affective and continuous basis has a significant effect on service quality. Conversely, it supports the findings of Hidayat's research (2010) which found that the organizational commitment on the normative basis insignificantly affects to the service quality. Based on the analysis of research results, it can be concluded that the organizational commitment variable does not affect significantly the variable of service quality in the Procurement Unit of Ministry of Finance (second hypothesis is rejected). The Influence of Organizational Support Perception on Service Quality

The result of the path coefficient test in Table 6 shows that the perception of organizational support insignificantly affects the service quality. This relationship defines that the high perception of organizational support given by the leaders of the organization has not been able to improve the service quality. This is due to the members of the ULP working group who assume that the organizational support is still less than optimal.

Surjadi (2012: 9) claims that the public service quality always involves three main elements; one of them is the institutional element or organization of service providers. One of the organizational aspect of service providers is the optimal organizational support given to the employees. It can be concluded that the employees who have a high perception of support from their organization will produce the excellent service quality.

The results of this research do not support the researches of DonHee et al. (2011) and Garg et al. (2014) explain that the perception of organizational support has a significant effect on the service quality. Based on the analysis of research results, it shows that the variable of perception of organizational support insignificantly affects the variable of service quality in Procurement Unit of Ministry of Finance (third hypothesis denied).

The Influence of Competence on ULP Working Group Performance

The result of the path coefficient test in Table 6 shows that competence insignificantly affects the performance of ULP working group. This relationship indicates that the high competence of ULP working group has not been able to improve the performance of ULP working group. This is due to the attitude of members of ULP working group that have not optimally used their knowledge and skills yet in completing the tasks of ULP working group.

Mc.Clelland in Sedarmayanti (2013: 126) explains that competence is a fundamental character of a person which directly affects the performance. Thus, someone will be difficult to complete a job without good competence, in accordance with the required standards.

The findings of this research do not support the researches of Sriwidodo and Haryanto (2010) and Ardiana et al. (2010) which claim that the competence has a significant effect on the performance. However, this research supports Ratnasari's research (2016) which defines the competence has an insignificant effect on performance. Based on the analysis of research results, it concludes that the variable of competence had an insignificant effect on the variable of ULP working group performance in Procurement Service Unit of Ministry of Finance (fourth hypothesis rejected).

The Influence of Organizational Commitment on ULP Working Group Performance

The result of the path coefficient test in Table 6 shows that the 


\section{Ahmad Roziq et al / The Effect of Competence, Organizational Commitment, and Perceived Organizational Support towards Service Quality and Working Group Performance of Procurement Service Unit in Ministry of Finance of Indonesia}

organizational commitment has insignificant effect on the performance of ULP working group. This relationship indicates that high organizational commitment consisting of affective commitment, continuance commitment and normative commitment is still not able to improve the performance of ULP working group. Based on the result of the research, the normative commitment indicator has the lowest correlation value with its construct compared with the correlation value of indicator of affective commitment and continuance commitment. It is indicated by the large number of ULP working group members who want to resign as members of the ULP working group.

Siagian (2002) states that several factors affecting the performance of public organizations are organizational commitment, organizational culture, and job satisfaction. The organizational commitment is important in achieving the organizational goals. To reach the goal, the individuals of the organization should exercise their rights and responsibilities in accordance with their duties and functions within the organization. The decline of the organizational commitment of the employees causes the low organizational performance.

The findings of this research do not support the researches of Hafidhah and Herli (2014) and Kurniawan (2013) which explain that the organizational commitment has a significant effect on performance. On the other hand, it supports the research of Abdullah and Arisanti (2010) which defines that the organizational commitment has insignificant effect on the organizational performance. They claims that the failure to achieve the goal is due to the low organizational commitment of the employees caused by the influence of the role conflict and work stress. Based on the analysis of research results, it concludes that the variable of organizational commitment has an insignificant effect on the variable of ULP working group performance in Procurement Service Unit in Ministry of Finance (fifth hypothesis rejected).

The Influence of Organizational Support on ULP Working Group Performance

The result of the path coefficient test in Table 6 shows that the perception of the organizational support has insignificant effect on the performance of ULP working group. This relationship indicates that the high perceptions of organizational support given by the leaders of the organization have not been able to improve the performance of ULP working group. This is due to the large number of ULP working group members who assume that the organizational support is inadequate, whether it is the perception of valuation, cares and well-being.

Mathis and Jackson in Kaswan (2015: 248) explain that the performance of employees is influenced by three factors: (1) the ability of individuals, (2) the effort, and (3) the organizational support. The organizational support consists of training and development, equipment and technology, job standards and performance management. If all three factors are owned by the employees, their performance will increase. Conversely, their performance will decrease if they do not hold one or two factors.
The findings of this research do not support the researches of Indarjanti et al. (2012) and Susmiati et al. (2015) which explain that the perception of organizational support has a significant effect on the performance. On the other hand, the results of this research support the research of Kambu, et al. (2011) which determines that the perception of organizational support insignificantly affects it. According to him, it indicates that the organizational support provided by the Regional Secretariat of Papua is perceived as the inadequate (low) one by its employees. Based on the analysis of research results, it concludes that the variable of organizational support perception insignificantly affects the variable of ULP working group performance in Ministry of Finance (the sixth hypothesis was rejected).

The Influence of Service Quality on ULP Working Group Performance

The result of the path coefficient test in Table 6 shows that the service quality significantly influences the performance of ULP working group. This relationship defines that the high reliability, responsiveness, assurance, and empathy of service quality provided by the ULP working group to service users will improve the performance of ULP Working Group.

Kawahe, et al. (2016) describes the factors that influence the organizational performance, like how the organization performs the service function to the public. A quality public service improves the organizational performance and gains the trust of the community. The existence of trust from service users will encourage the employees to take responsibility of their actions. Therefore, the service quality is one factor that influences the performance of public organizations.

The results of this research support the research of Churiyah (2007) and Kawahe, et al. (2016) which explain that the service quality significantly affects the performance of the organization. According to Kawahe, et al. (2016), the quality of public services and the performance of the organization have linear patterns of functional relationships. If the public service quality improves, it will encourage the improvement of organizational performance. Based on the analysis of research results, the variables of service quality have no significant effect on the variables of ULP working group performance in Ministry of Finance (the sixth hypothesis is rejected).

\section{Conclusion}

Based on the results of data analysis and discussion explained before, it draws some conclusions:

1. The competence has a significant effect on the variable of service quality in Procurement Service Unit of Ministry of Finance. The results of this research indicate that the first hypothesis defining the competence has a significant effect on the service quality is received.

2. The organizational commitment insignificantly affects the variable of service quality in Procurement Service Unit of Ministry of Finance. The results of this research indicate that the second hypothesis defining the organizational commitment has a significant effect on the service quality is rejected. 
Ahmad Roziq et al / The Effect of Competence, Organizational Commitment, and Perceived Organizational Support towards Service Quality and Working Group Performance of Procurement Service Unit in Ministry of Finance of Indonesia

3. The organizational support insignificantly affects the variable of service quality in Procurement Service Unit of Ministry of Finance. The results of this research indicate that the third hypothesis defining the perception of the organizational support has a significant effect on the service quality is rejected.

4. The competence insignificantly affects the variable of ULP working group performance in Procurement Service Unit of Ministry of Finance. The results of this research indicate that the fourth hypothesis defining the competence has a significant effect on the performance of ULP working group is rejected.

5. The organizational commitment insignificantly affects the variable of ULP working group performance in Procurement Service Unit of Ministry of Finance. The results of this research indicate that the fifth hypothesis defining the organizational commitment has a significant effect on the performance of ULP working group is rejected.

6. The organizational support insignificantly affects the variable of ULP working group performance in Procurement Service Unit of Ministry of Finance. The results of this research indicate that the sixth hypothesis defining the perception of the organizational support has a significant effect on the performance of ULP working group is rejected.

7. The service quality significantly affects the variable of ULP workgroup in Procurement Service Unit of Ministry of Finance. The results of this research indicate that the seventh hypothesis defining the service quality has a significant effect on the performance ULP working group is received.

\section{Suggestion}

Based on the discussion and conclusion above, the suggestions of this research are:

1. The leader of organization needs to increase the organizational commitment of ULP Working Group, especially about the normative commitment in which there are still a lot of members of ULP Working Group that want to quit their job.

2. The leader of organization needs to improve the service quality of ULP Working Group, especially related to the tangible quality by providing meeting rooms for ULP working group and the help desk for service users.

3. The leader of organization needs to improve the effectiveness of procurement indicated by the respondents' perception that the technical capability of goods / services and the auction winner provider is not compatible with the work unit expectation.

\section{Bibliography}

[1] Abdullah, and Arisanti, H. 2010. Pengaruh Budaya Organisasi, Komitmen Organisasi dan Akuntabilitas Publik terhadap Kinerja Organisasi. Jurnal Ekonomi dan Bisnis. 9(2): 118-113
[2] Ardiana, I.D.K.R., I.A. Brahmayanti, and Subaedi. 2010. Kompetensi SDM UKM dan Pengaruhnya Terhadap Kinerja UKM Surabaya. Jurnal Manajemen dan Kewirausahaan 12(1): 42-45.

[3] Churiyah, M. 2007. Peranan Kualitas Pelayanan Terhadap Kinerja Rumah Sakit (Studi pada Rawat Inap Rumah Sakit Islam WAFA Kepanjen Kabupaten Malang). Jurnal Ekonomi Modernisasi. 3(2): 103-113.

[4] DonHee, L., C. Soong-Hwan, and C. Kanghwa. 2011. The Impact of Perceived Organizational Support on Service Quality, Customer Satisfaction, and Customer Loyalty in the Health Care Service. Journal of Korea Service Management Society. 12(1): 133-154.

[5] Garg, S., and R. L. Dhar. 2014. Effects of Stress, LMX and Perceived Organizational Support on Service Quality: Mediating Effects of Organizational Commitment. Journal of Hospitality and Tourism Management. 21: 64-75.

[6] Gunadi, A. Irawan, S. L. Ratnasari, and C. Wibisono. 2015. Kualitas Pelayanan Sebagai Variabel Intervening Antara Kompetensi Pegawai dan Budaya Kerja Terhadap Kepuasan Mitra di Pelayanan Terpadu Satu Pintu Badan Pengusahaan Kawasan Perdagangan Bebas dan Pelabuhan Bebas Batam. Jurnal Akuntansi, Ekonomi dan Manajemen Bisnis. 3(1): 56-65.

[7] Hafidhah, and M. Herli, 2014. Pengaruh Budaya Organisasi, Komitmen Organisasi, dan Akuntabilitas Publik Terhadap Kinerja Rumah Sakit di Kabupaten Sumenep. Jurnal Performance Bisnis dan Akuntansi. 4(2):1-13.

[8] Hidayat, M. 2014. Analisis Komitmen (Affective, Continuance dan Normative) Terhadap Kualitas Pelayanan Pengesahan STNK Kendaraan Bermotor (Studi Empiris pada Kantor Bersama Samsat di Propinsi Kalimantan Timur). Jurnal Manajemen dan Kewirausahaan. 12(1): 11-23.

[9] Indarjanti, P., and T. Bodroastuti. 2012. Pengaruh Kemampuan, Usaha Dan Dukungan Organisasi Terhadap Kinerja. Jurnal Kajian Akuntansi dan Bisnis. 1(1): 64-83.

[10] Ivancevich, J.M., R. Konopaske, and M.T. Matteson. 2005. Organizational Behavior and Management, Seventh Edition. New York: McGraw-Hill Companies. Terjemahan oleh Gina Gania. 2007. Perilaku Organisasi dan Manajemen. Edisi Ketujuh. Jakarta: Penerbit Erlangga.

[11] Kaswan. 2015. Sikap Kerja : Dari Teori dan Implementasi sampai Bukti. Bandung: Alfabeta.

[12] Kawahe, L., F.M.G. Tulusan, and B. Kiyai. 2016. Pengaruh Kualitas Pelayanan Publik Terhadap Kinerja Organisasi (Studi Pada Dinas Kependudukan Dan Catatan Sipil Kabupaten Minahasa Tenggara). Jurnal Administrasi Publik. 1(37): 1-10.

[13] Keputusan Menteri Pendayagunaan Aparatur Negara Nomor 63/KEP/M.PAN/7/2003. Pedoman Umum Penyelenggaraan Pelayanan Publik. Jakarta.

[14] Kambu, A., E.A. Troena, Surachman, and M. Setiawan. 
Ahmad Roziq et al / The Effect of Competence, Organizational Commitment, and Perceived Organizational Support towards Service Quality and Working Group Performance of Procurement Service Unit in Ministry of Finance of Indonesia

2012. Pengaruh Leader-Member Exchange, Persepsi Dukungan Organisasional, Budaya Etnis Papua dan Organizational Citizenship Behavior terhadap Kinerja Pegawai pada Sekda Provinsi Papua. Jurnal Aplikasi Manajemen. 10(2): 262-272.

[15] Kurniawan, M. 2013. Pengaruh Komitmen Organisasi, Budaya Organisasi dan Kepuasan Kerja Terhadap Kinerja Organiasi Publik (Studi Empiris pada SKPD Pemerintah Kabupaten Kerinci). Jurnal Akuntansi. 1(3): $1-27$.

[16] Nurmasitha, F., A. Hakim, W.Y. Prasetyo. 2013. Pengaruh Kompetensi Pegawai dan Lingkungan Kerja Terhadap Kualitas Pelayanan (Studi pada Dinas Kependudukan dan Pencatatan Sipil Kabupaten Sidoarjo). Jurnal Administrasi Publik. 1(6): 1220-1228.

[17] Prabowo, A. 2015. Perkembangan ULP dan Jabatan Fungsional PPBJ. Makalah Rapat Koordinasi Ahli Pengadaan Barang/Jasa dan ULP Tahun 2015. Medan,10 Juni.

[18] Sedarmayanti. 2013. Manajemen Sumber Daya Manusia, Reformasi Birokrasi dan Manajemen Pegawai Negeri Sipil. Bandung : PT Refika Aditama.

[19] Sumarsono, S. 2017. Penguatan Organisasi Fungsi Pengadaan Kementerian Keuangan. Makalah Sosialisasi Program Modernisasi Pengadaan Kementerian Keuangan. Jakarta : Rapat Koordinasi Nasional Pengadaan Kementerian Keuangan 2017. 25 Januari.

[20] Ratnasari, S.L. 2016. Pengaruh Kompetensi dan Kompensasi Terhadap Kinerja Karyawan Departemen Quality Assurance PT. PEB Batam. Prosiding Seminar Nasional Ekonomi dan Bisnis Universitas Muhammdiyah Sidoarjo: 424-434.

[21]Siagian, Sondang P. 2002. Kiat Meningkatkan Produktivitas Kerja. Jakarta: PT Rineka Cipta.

[22] Sriwidodo, U., and A.B. Haryanto. 2010. Pengaruh Kompetensi, Motivasi, Komunikasi dan Kesejahtaraan Terhadap Kinerja Pegawai Dinas Pendidikan. Jurnal Manajemen Sumber Daya Manusia. 4(1): 47-57.

[23] Sujarwo, A.B.S. 2016. Pengaruh Keterampilan, Motivasi Dan Komitmen Terhadap Kualitas Pelayanan KTP Aparat Pemerintah Desa Dan Kelurahan Di Kecamatan Pandan Tapanuli Tengah. Jurnal Bisnis dan Manajemen Eksekutif . 1(1): 1-18.

[24] Surjadi, H. 2012. Pengembangan Kinerja Pelayanan Publik. Cetakan ke-2. Jakarta: PT Refika Aditama.

[25] Susmiati, and K. Sudarma. Pengaruh Budaya Organisasi dan Dukungan Organisasi Persepsian Terhadap Kinerja Karyawan Dengan Komitmen Organisasi Sebagai Variabel Intervening. Jurnal Manajemen Analisis Eksekutif. 4(1): 79-87.

[26] Warta Eproc. 2016. Menkeu Tandatangani MOU Program Modernisasi Pengadaan. No. XVI. Jakarta. Page 31.

[27] Wibowo. 2011. Manajemen Kinerja Edisi Ketiga. $4^{\text {th }}$ Print. Jakarta: PT Rajagrafindo Persada. 